\title{
IMPLEMENTASI PENGGUNAAN POSITION POWER DAN PERSONAL POWER SERTA PENGARUHNYA TERHADAP KINERJA PEGAWAI UNIVERSITAS ISLAM NEGERI (UIN) MALANG
}

\author{
Achmad Sani Suprianto \\ Fakultas Ekonomi Universitas Islam Negeri (UIN) Malang
}

\begin{abstract}
The Study aims at, 1) finding out the simultaneuos influence of position power, and personnal power on the performance. 2) finding out the partially influence of position power, and personnal power on the performance. This is an explanatory research involving the employees of UIN Malang as the analysis unit. The studi used proportional random sampling method and to collect data from 36 respondent a questionnaire was used. The analysis technique used were multiple regression, partial regression, and determination. The result of study showed that :1) simultaneously the position power, and personnal power significantly influenced the performance, 2) partially the position power, personnal power had also positive influence on the performance. Based on the finding, therefore it is suggested that the organization UIN Malang more attention to personnal potveer, is basically a dominant variable in influencing performance.
\end{abstract}

Key words: position power, personnal power, and performance 


\section{Pendahuluan}

Potensi Sumber Daya Manusia pada hakekatnya merupakan salah satu modal dasar pembangunan. Namun masih dirasakan bahwa potensi Sumber Daya Manusia tersebut belum dapat dimanfaatkan secara optimal mengingat sebagian besar dari angkatan kerja memiliki kemampuan yang berbeda sebagai akibat dari latar belakang pendidikan, pengalaman, dan lingkungan kerja yang beraneka ragam. Hal ini akan terbawa juga dalam hubungan kerjanya sehingga akan mempengaruhi sikap dan tingkah laku pegawai dalam melaksanakan pekerjaannya.

Salah satu aspek yang perlu untuk segera diperhatikan guna pembenahan, pembinaan secara terus-menerus adalah peningkatan mutu pegawai dan memperbaiki metode kerja dengan menjamin agar para pegawai dapat melaksanakan tugas secara optimal, tanpa mengalami berbagai gangguan yang dapat mempengaruhi kinerja. Manuaia adalah yang menjadi perencana, pelaku dan penentu dari organisasi, karena itu alat secanggih apapun tidak akan mempunyai kcgunaan, jika peran aktif Sumber Daya Manusia tidak diikutsertakan. Bertumpu pada Sumber Daya Manusia yang berkualitas tentunya kinerja organisasi dapat ditingkatkan.

Organisasi yang berhasil dan sukses tidak hanya ditentukan oleh kemampuan teknik semata-mata, akan tetapi berkaitan erat dengan persoalan manusia yang berkenaan dengan keteraturan perilaku orang-orang dalam interaksi, berkembangnya norma-norma dan kelompok kerja, nilai-nilai organisasi, serta falsafah yang menjadi landasan kebijakan organisasi yang berkaitan dengan pegawai.

Agar pegawai dapat bekerja secara efisien dan efektif, maka kepemimpinan memegang peranan penting untuk dapat mempengaruhi dan menggerakkan bawahan untuk mencapai tujuan organisasi. Pemimpin dituntut untuk memberikan dorongan kepada pegawai, sehingga kinerja pegawai dapat ditingkatkan. Karena pada dasarnya, kinerja tidak timbul dengan mudah, namun kinerja timbul secara ekstern maupun secara intern dengan memberikan stimulus seperti motivasi, komunikasi, pengendalian, penggunaan kekuasaan dan gaya kepemimpinan. 
Pemimpin yang efektif harus berhubungan dengan tujuan-tujuan individu, kelompok dan organisasi. Keefektifan pemimpin khususnya dipandang menurut derajat pencapaian satu atau kombinasi dari tujuan individu, mungkin memandang pemimpin yang efektif atau tidak menurut kepuasan yang mereka terima dari total pengalamannya. Dan dalam kenyataannya, penerimaan perintah atau permintaan pemimpin sangat bertumpu pada harapan-harapan pengikut, sehingga respon yang menyenangkan akan mengarahkan pada hasil-hasil yang baik (Gibson, Ivancevich, Donnely, 1996).

Pemimpin dalam melaksanakan kepemimpinannya tidak akan terlepas dari penggunaan kekuasaan. Kekuasaan yang dipunyai pemimpin merupakan alat untuk menggerakkan bawahannya (Northouse, 1997). Dalam rangka mempengaruhi orang lain untuk mencapai tujuan organisasi, maka seorang pemimpin perlu memiliki kekuasaan dan bisa menggunakannya secara efektif. Para pemimpin sukses harus mampu menggunakan kekuasaan terhadap para bawahan, memerintahkan pada mereka apa yang mesti dilakukan, dan menerapkan sanksi positif dan negatif secara tepat. Seseorang yang tidak sanggup menggunakan kekuasaannya akan mendapatkan kesulitan dalam menjalankan peran kepemimpinannya. Lebih lanjut dikatakan, bahwa para pemimpin yang sukses menetapkan contoh-contoh terlibat dalam perilaku simbolik yang memberitahu para pengikut apa yang diharapkan dari mereka, juga memberitahu perilaku-perilaku seperti apa yang layak. Kemudian dikatakan juga, bahwa untuk mencapai umpan balik yang berguna dan tepat, harus ada ukuran kinerja yang cermat untuk menaksir tingkat yang dibutuhkan demi tercapainya kinerja yang optimal. Pemimpin harus merancang sebuah sistem dimana tindakan atau kinerja pegawai bisa diukur secara obyektif (Locke, 1991).

Universitas Islam Negeri (UIN) Malang adalah salah satu perguruan tinggi Islam terbesar di Jawa Timur, yang mengembangkan ilmu-ilmu kegamaan (Islamic Studies) dan ilmu-ilmu umum. Mengingat peran penting yang dimainkan oleh UIN Malang sebagai organisasi yang bergerak di bidang pendidikan dan pengajaran, memberikan pelayanan yang terbaik kepada mahasiswa, maka faktor kepemimpinan merupakan salah satu faktor dalam 
meningkatkan kinerja karyawan, selain ditentukan oleh faktor iklim organisasi yang sehat. Pemimpin dalam organisasi akan menggunakan dua model kekuasaan, yaitu personal power dan position power untuk dapat meningkatkan kinerja pegawai (Hersey, 1986). Penggunaan kedua kekuasaan ini akan berpengaruh terhadap peningkatan kinerja karyawan. Demikian pentingnya kekuasaan ini dalam meningkatkan kinerja, maka penelitian ini ingin mengkaji lebih mendalam mengenai "Implementasi Penggunaan Position Power Dan Personnal Power serta Pengaruhnya Terhadap Kinerja Pegawai Universitas Islam Negeri (UIN) Malang".

\section{Metode Penelitian}

Dalam penelitian ini menggunakan metode eksplanatori (explanatory research) adalah untuk menguji hipotesis antar variabel yang dihipotesiskan. Pada penelitian ini terdapat hipotesis yang akan diuji kebenarannya. Hipotesis itu sendiri menggambarkan hubungan antara dua variabel, untuk mengetahui apakah suatu variabel berasosiasi ataukah tidak dengan variabel lainnya, atau apakah variabel disebabkan atau dipengaruhi atau tidak oleh variabel lainnya (Faisal, 1992). Populasi pada penelitian ini adalah seluruh pegawai administrasi Universitas Islam Negeri Malang sejumlah 75 orang. Sampel dalam penelitian ini adalah 36 pegawai. Teknik pengambilan sampel yang digunakan adalah teknik simpel random sampling, yaitu teknik pengambilan sampel dimana semua anggota mempunyai kesempatan yang sama untuk dijadikan sampel (Sugiyono, 1999 : 78). Agar sampel yang diambil dapat dikatakan representatif maka dalam penelitian ini ditentukan ukuran sampel yang dihitung dengan menggunakan rumus T. Yamane (Rahmad, 1989 : 71), sebagai berikut:

$$
\mathrm{n}=\frac{\mathrm{N}}{\mathrm{N}(\mathrm{d})^{2}+1}
$$

Dimana:

$$
\begin{aligned}
& \mathrm{n}=\text { ukuran sampel } \\
& \mathrm{N}=\text { jumlah populasi } \\
& \mathrm{d}=\text { presisi }
\end{aligned}
$$


Variabel dalam penelitian ini terdiri däri : (1) Penggunaan kekuasaan posisi (x1), (2) Penggunaan kekuasaan pribadi (x2). Variabel Kinerja Pegawai $(Y)$ sebagai variabel terikatnya

\section{Hasil}

Tabel Rekapitulasi Analisis Regresi Linier Berganda Pengaruh Variabel Penggunaan Kekuasaan Posisi (X1) dan Pengaruh Kekuasaan Pribadi (X2) Terhadap Kinerja Pegawai (Y).

\begin{tabular}{|l|c|c|c|c|c|}
\hline $\begin{array}{c}\text { Variabel } \\
\text { Bebas }\end{array}$ & $\begin{array}{c}\text { Koefisien } \\
\text { Regresi (B) }\end{array}$ & $\begin{array}{c}\mathrm{T} \\
\text { Hitung }\end{array}$ & Probabilit & $\begin{array}{c}\text { Koefisien } \\
\text { Determinasi } \\
\text { Parsial }\end{array}$ & $\begin{array}{c}\text { Keputusan } \\
\text { Terhadap } \\
\text { Ho }\end{array}$ \\
\hline Konstanta & 1,127 & 1,356 & 0,184 & & \\
\hline $\mathrm{X} 1$ & 0,587 & 3,120 & 0,004 & 0,394 & Ditolak \\
\hline $\mathrm{X} 2$ & 0,657 & 4,192 & 0,000 & 0,529 & Ditolaḱ \\
\hline $\mathrm{R}^{2}$ disesuaikan $=0,575$ & & F hitung $=14,913$ \\
Multiple (R) $=0,789$ & Probabilitas $=0,000$ \\
$\mathrm{~N}$ & $=36$ & & $\alpha=0,05$ \\
\hline
\end{tabular}

Sumber : Hasil Analisis

Hasil perhitungan dalam tabel diatas diperoleh persamaan regresi linier berganda sebesar: $Y=1,127+0,587 \times 1+0,657 \times 2$. Dari hasil ini dapat dijelaskan bahwa konstanta 1,127 berarti jika tidak ada xi, maka kinerja pegawai adalah sebesar 1,127 . Jika nilai koefisien regresi variable $x 1$ dan $x 2$ dinaikkan satu satuan, maka kinerja pegawai akan meningkat secara berturut-turut sebesar $58,7 \%(x 1)$ dan $65,7 \%(x 2)$.

Pada Tabel dapat diketahui bahwa nilai $F$ hitung adalah sebesar 14,913 dengan nilai $p<0,05$, maka Ho ditolak Hal ini berarti berdasarkan hasil penelitian penggunaan kekuasaan posisi dan penggunaan kekuasaan pribadi secara simultan mempunyai pengaruh yang signifikan terhadap kinerja pegawai, dengan demikian hipotesis (1) dapat diterima.

Ulul Albab, Vol. 9 No. 1, 2008 
Nilai multiple $\mathrm{R}$ sebesar 0,789 , ini mengandung makna bahwa terdapat hubungan yang erat antara variabel penggunaan kekuasaan posisi (X1), penggunaan kekuasaan pribadi (X2) dengan kinerja pegawai (Y). Variasi perubahan nilai variabel kinerja pegawai $(Y)$ yang dapat dijelaskan oleh seluruh variabel bebas; penggunaan kekuasaan posisi (X1) dan penggunaan kekuasaan pribadi (X2) yang ditunjukkan oleh angka koefisien determinasi yang disesuaikan yaitu sebesar 0,575 atau sebesar $57,5 \%$, dan sisanya sebesar $42,5 \%$ dipengaruhi oleh variabel lain.

Berdasarkan pengujian secara parsial terhadap masing-masing variabel bebas dapat diketahui:

1. Hasil analisis regresi penggunaan kekuasaan posisi $(\mathrm{X} 1)$ terhadap kinerja pegawai (Y) pada Tabel 11 menunjukkan nilai $p(0,004)<a(0,05)$. Ini berarti secara parsial ada pengaruh yang signifikan antara penggunaan kekuasaan posisi terhadap kinerja pegawai pada taraf signifikansi $95 \%$. Nilai kocfisicn determinasi parsial yang diperoleh sebesar 0,394 , berarti variasi perubahan kinerja pegawai $(\mathrm{Y})$ yang dapat dijelaskan oleh variabel penggunaan kekuasaan posisi (X1) sebesar 39,4\%. Nilai koefisien regresi (B) yang diperoleh positif, yaitu sebesar 0,587 .

2. Hasil analisis regresi penggunaan kekuasaan pribadi $(X 2)$ terhadap kinerja pegawai $(Y)$ pada Tabel 11 menunjukkan nilai $p(0,000)<$ a $(0,05)$. Ini berarti secara parsial ada pengaruh yang signifikan antara penggunaan kekuasaan pribadi terhadap kinerja pegawai pada taraf signifikansi $95 \%$. Nilai koefisien determinasi parsial yang diperoleh sebesar 0,529, berarti variasi perubahan kinerja pegawai $(\mathrm{Y})$ yang dapat dijelaskan oleh variabel penggunaan kekuasaan pribadi (X2) sebesar 52,9\%. Nilai koefisien regresi (B) yang diperoleh positif, yaitu sebesar 0,657.

Berdasarkan hasil analisis regresi parsial variabel bebas terhadap variabel terikat pada Tabel 11 menunjukkan nilai $p<0,05$ untuk masingmasing variabel bebas, maka $\mathrm{HO}$ ditolak. $\mathrm{Hal}$ ini berarti penggunaan kekuasaan posisi dan penggunaan kekuasaan pribadi secara parsial 
mempunyai pengaruh yang signifikan terhadap kinerja pegawai. Dengã̃ demikian hipotesis (1) yang menyatakan ada pengaruh yang signifikan penggunaan kekuasaan berupa penggunaan kekuasaaan posisi dan penggunaan kekuasaan pribadi terhadap kinerja pegawai baik secara bersama-sama maupun secara parsial dapat diterima.

Untuk mengetahui variabel manakah diantara kedua penggunaan kekuasaan posisi, dan penggunaan kekuasaan pribadi yang berpengaruh dominan terhadap kinerja pegawai, dapat dilihat pada hasil pengujian pengaruh secara bersama-sama antara variabel penggunaan kekuasaan posisi (X1), penggunaan kekuasaan pribadi (X2) terhadap kinerja kinerja pegawai (Y) yang mempunyai thitung dan koefisien determinasi paling besar.

Pada Tabel dapat diketahui ternyata variabel penggunaan kekuasaan pribadi mempunyai t hitung dan koefisien determinasi parsial paling besar dari variabel lainnya. Jadi dapat disimpulkan bahwa variabel penggunaan kekuasaan posisi mempunyai pengaruh dominan terhadap kinerja pegawai (Y), dengan thitung sebesar 4,192 dan koefisien determinasi parsial sebesar 0,529 .

\section{Pembahasan}

Berdasarkan hasil penelitian diUniversitas Islam Negeri (UIN) Malang, menunjukkan bahwa variabel penggunaan kekuasaan (penggunaan kekuasaan posisi, dan penggunaan kekuasaan pribadi) secara simultan mempunyai pengaruh yang signifikan terhadap kinerja pegawai $(p=0,000$ $<0,05)$. Variasi perubahan nilai kinerja pegawai yang dapat dijelaskan oleh seluruh variabel bebas; (penggunaan kekuasaan posisi, dan peng-gunaan kekuasaan pribadi) secara simultan sebesar $54,3 \%$, selebihnya sebesar $45,7 \%$ dijclaskan olch variabel lain. Hal ini dapat diartikan bahwa pengaruh penggunaan kekuasaan posisi dan penggunaan kekuasaan pribadi dalam peningkatan kinerja pegawai adalah sebesar $54,3 \%$, sehingga penggunaan kekuasaan ini sangat penting dalam menaikkan kinerja pegawai.

Hasil ini sejalan dengan adanya pemikiran bahwa pada dasamya kinerja merupakan hasil usi'ía yang disebabkan oleh usaha bersama dari ketrampilan 
yang dimiliki seseorang, pengaruh perilaku pemimpin, serta kekuasaan yang dimiliki oleh pemimpin tersebut (Yukl, 1998).

Secara teoritis, hasil penelitian ini mendukung pemikiran, bahwa seorang pemimpin yang berhasil baik dalam pencapaian tujuan organisasi, yaitu peningkatan kinerja (individu dan organisasi) yang baik serta kepuasan adalah seseorang yang mengetahui sumber kekuasaan dan pentingnya kekuasaan yang dirasakan, di dalam pencapaian tujuan tidak hanya tergantung pada sumber-sumber kekuasaan dan persepsi saja, tetapi juga kebutuhan pengikut, situasi dan pengalaman serta gaya pemimpin dalam menjalankan tugas (Gibson, 1996).

Hasil penelitian ini secara teoritis mendukung konsep yang dipaparkan Etzioni, bahwa situasi terbaik bagi para pemimpin adalah apabila mereka memiliki kedua jenis kekuasan itu, yaitu kekuasaan posisi dan kekuasaan pribadi (Herseydan Blanchard, 1986). Hal senada diungkapkan oleh Provan, kekuasaan tidak harus hanya kekuasaan posisi tetapi juga kekuasaan pribadi jika ingin dicapai prestasi atau kinerja yang optimal (Gibson, 1996).

Secara teoritis, penelitian ini mendukung konsep yang dipaparkan Robbins, bahwa penggunakan kekuasaan yang efektif dapat mendorong kinerja, komitmen dan kepuasan kerja yang lebih tinggi (Robbins, 1996). Begitu juga dengan Franklin yang menyatakan bahwa sesungguhnya kekuasaan berpengaruh pada kinerja, kepuasan kerja dan komitmen pada organisasi (Soetjipto, 2000). Bahkan ditegaskan juga bahwa pemilihan kekuasaan secara tepat dan efektif dapat meningkatkan kinerja karyawan (Weiss, 1988).

Hasil penelitian di lapangan menunjukkan bahwa penggunaan kekuasaan posisi merupakan variabel yang dominan dalam mempengaruhi kinerja pegawai dibandingkan variabel bebas lain. Hal ini didukung oleh adanya data hasil penelitian di lapangan, bahwa penggunaan kekuasaan posisi mempunyai $t$ hitung dan koefisien determinasi parsial paling besar.

Berdasarkan penelitian ini, maka secara teoritis mendukung adanya pemikiran bahwa pada dasamya yang terbaik bagi seorang pemimpin adalah 
memiliki keduanya yaitu memiliki hubungan yang didasarkan oleh rasa kasih (kuasa pribadi) dan memiliki hubungan yang didasarkan oleh rasa takut (kuasa posisi). Tapiapabila orang tidakdapat memiliki keduanya, hubungan yang didasarkan rasa kasih cenderung rawan, berumur singkat, dan mudah hilang, bila tidak ada rasa takut akan pembalasan. Sebaliknya hubungan yang didasarkan rasa takut cenderung berlangsung lebih lama (Hersey dan Blanchard, 1986).

Hasil penelitian di lapangan sejalan dengan adanya pemikiran bahwa pujian oleh atasan meningkatkan kinerja bawahan (Yukl, 1998). Secara konseptual, dari hasil penelitian ini apabila orang-orang dalam organisasi lebih mementingkan keberhasilan, maka cenderung mengutamakan kuasa posisi dan menerapkan supervisi yang ketat. Kuasa posisi cenderung didelegasikan ke bawah melalui struktur organisasi. Lebih lanjut dikatakan kuasa posisi adalah sesuatu yang harus diperoleh manajer secara rutin (Hersey dan Blanchard, 1986).

Seorang pemimpin yang memahami secara kelimuan tentang kekuasaan pasti akan mengakui bahwa kekuasaan itu merupakan alat untuk melaksanakan kepemimpinan. Dari dua macam kekuasaan yang digunakan dalam penelitian ini, terbukti memang ada dalam praktek kepemimpinan. Penggunaan kekuasaan posisi yang dijabarkan dalam kekuasaan legitimasi, kekuasaan ganjaran, dan kekuasaan paksaan berpengaruh terhadap kinerja. Hal ini menunjukkan bahwa jabatan atau kedudukan dalam organisasi masih dianggap sebagai salah satu faktor yang diperhitungkan untuk mempengaruhi cara kerja pegawai. Disamping itu nampak bahwa para pegawai masih menghormati jabatan pimpinannya. Hukuman perlu dilakukan dalam artian bukan untuk menakut-nakuti tetapi untuk meng-hindari terjadinya kesalahan berulang.

Penggunaan kekuasaan pribadi dijabarkan dalam kekuasaan keahlian dan referensi. Model kekuasaan ini ditandai dengan kekaguman pegawai terhadap penampilan pimpinan, dimana pimpinan memiliki daya tarik serta kepribadian tinggi, sehinggga membuat para pegawai mempunyai semangat 
kerja yang tinggi. Penggunaan kekuasaan keahlian penting terutama dalam membangkitkan semangat kerja pegawai untuk bekerja lebih baik.

Dalam pandangan Islam kekuasaan itu ada pada setiap diri seseorang yang harus dipergunakan dan dilaksanakan dengan baik. Hal ini sesuai dengan hadist Nabi yang berbunyi: Dari Ibnu Umar RA bahwasannya beliau bersabda: "setiap orang dari kalian adalah seorang pemimpin dan bertanggung jawab terhadap kepemimpinannya. Seorang penguasa adalah pemimpin dan bertanggung jawab terhadap rakyat yang dipimpinnya, seorang suami adalah pemimpin dan bertanggung-jawab terhadap keluarganya, seorang dari istri bertanggung jawab terhadap urusan rumah dan anakanaknya. Kalian semua adalah pemimpin dan bertanggung-jawab terhadap kepemimpinan kalian. (HR Bukhari: 4801, Muslim: 3408, Tirmidzi: 1627, Abu Dawud: 2539, dan Ahmad: 4266, 4920, 5603, 5635, 5753).

Dalam hadits diriwatkan oleh Bukhari dan Muslim bahwa: Rasulullah SAW bersabda:" Orang kuat itu bukan karena ototnya, akan tetapi orang kuat adalah orang yang bisa mengendalikan diri dalam suasana marah". (HR Bukhari: 5649, Muslim: 4723)

\section{Simpulan}

Penelitian ini bertujuan untuk menguji implementasi penggunaan position power dan personal power serta pengaruhnya terhadap kinerja pegawai di Universitas Islam Negeri (UIN) Malang. Berdasarkan hasil analisis data dan pembahasan yang telah dilakukan, maka dapat ditarik kesimpulan sebagai berikut:

Berdasarkan hasil pengujian yang dilakukan dengan analisis regresi berganda, menunjukkan bahwa variabel kekuasaan posisi dan kekuasaan pribadi secara simultan mempunyai pengaruh yang signifikan terhadap semangat kerja anggota. Kesimpulan ini diperoleh berdasarkan tingkat probabilitas $(0,000)$ lebih kecil dari alpha 0,05 . Koefisien determinasi atau $\mathrm{R}^{2}$ disesuaikan sebesar 0,575 , yang berarti bahwa variasi perubahan nilai kekuasaan posisi dan kekuasaan pribadi dapat dijelaskan oleh seluruh variabel bebas secara simultan sebesar $57,5 \%$ selebihnya sebesar $42,5 \%$ 
dipengaruhi oleh variabel lain yang tidak diteliti. Jadi pengaruh kekuasaan posisi dan kekuasaan pribadi mampu dalam meningkatkan kinerja pegawai sebesar $57,5 \%$, sehingga kedua fator ini harus mendapatkan perhatian yang serius dari pimpinan agar tetap terjaga kinerja pegawai.

Berdasarkan hasil penelitian menunjukkan bahwa penggunaan kekuasaan pribadi mempunyai pengaruh yang dominan dalam meningkatkan kinerja pegawai, nilai probabilitasnya sebesar 0,000 , dan koedfisien determinasi parsial sebasar 0,529 . Dengan demikian hipotesis yang menyatakan bahwa kekuasaan posisi berpengaruh dominaan secara parsial dapat diterima.

Sedangkan saran yang dapat diberikan dari hasil penelitian ini antara lain:

1. Macam-macam kekuasaan yang digunakan dalam penelitian ini pada dasarnya baik, sepanjang tujuan yang akan dicapai untuk kepentingan organisasi merupakan prioritas utama. Namun melihat dan mencermati perkembangan dinamika pegawai yang semakin kompleks, maka para pimpinan harus secermat mungkin menempatkan dan mempraktekkan kekuasaan yang dimiliki secara proporsional. Hal ini dikarenakan bahwa penggunana kekuasaan yang baik akan mampu untuk meningkatkan kinerja pegawai

2. Penggunaan kekuasaan pribadi merupakan faktor dominan dalam meningkatkan kinerja pegawai, sehingga penggunaan kekuasaan ini perlu mendapatkan perhatian bagi para pimpinan. Model penggunaan kekuasaan pribadi dapat berupa sifat diri pemimpin yang mempunyai kharisma, punya kemampuan/keahlian yang dapat membantu dalam menyelesaikan permasalahan, dan mempunyai kepribadian yang baik yang dapat dijadikan uswah atau contoh bagi semua pegawai UIN Malang. 


\section{Daftar Pustaka}

Arikunto, Suharsimi. 1991. Prosedur Penelitian, Suatu Pendekatan Praktis. Jakarta: Penerbit Rineka Cipta.

As'ad, Moch. 1991. Psikologi Industri. Yogyakarta: Liberty.

Bernardin, H John \& Russell, Joyce E.A. 1993. Human Resources Management. New York: McGraw Hill.

Byars, Lloyd .L \& Leslie W. Rue. 1995. Human Resources And Personal Management. Inc, Illionis. USA: Richard D Irwin.

Djarwanto, P.S \& Subagyo, P. 1993. Seatistik Induktif.. Yogyakarta: Edisi IV. BPFE.

Faisal, Sanapiah. 1992. Format-Format Penelitian Sosial. Jakarta: Penerbit Rajawali.

Gibson, James, J.M Ivancevic and J.H Donnely. 1996. Organisasi; Perilaku, Struktur, Proses. Edisi kedelapan Jilid I. Terjemahan Nunuk Adiarni. Jakarta: Binarupa Aksara.

Hersey, Paul dan Kenneth H, Blanchard. 1986. Manajemen Perilaku Organisasi : Pendayagunaan Sumberdaya Manusia. Edisi Keempat. Terjemahan Agus Dharma. Jakarta: Erlangga.

Mangkunegara, A.P. 2001. Manajemen Sumber Daya Manusia Penusahaan. Edisi Baru. Bandung: Remaja Resdakarya.

Offerman, L R \& Hellman PS. 1997. Culture Consequences For Leadership Behaviour: National Values In Action. Journal Of Cross Culture Psychology. Vol 28. No. 3.

Robbins, Stephen. 1996. Perilaku Organisasi: Konsep, Kontroversi Dan Aplikasi. Edisi Kedua. Terjemahan Pudjaatmaka. Jakarta: Prenhallindo.

Santoso, Singgih. 2000. SPSS Mengolah Data Statistik Secara Profesional. Cetakan Kedua. Jakarta: Elex media Computindo. 
Sugiyono. 1999. Metode Penelitian Bisnis. Bandung: Penerbit Alfabeta.

Sugiarto. 1992. Tahap Awal Dan Aplikasi Analisis Regresi. Yogyakarta: Andi Offset.

Swasto, Bambang. 1996. Manajemen Sumber Daya Manusia. Malang: Fakultas Ilmu Administrasi. Universitas Brawijaya.

Usman dan Akbar SP. 2000. Pengantar Statistik. Jakarta: Bhumi Kasara.

Umar, H. 2001. Riset Sumber Daya Manusia Dalam Organisasi. Cetakan Keempat. Jakarta: Penerbit Gramedia Pustaka Utama.

Yukl, Gary. 1998. Leadership In Organization. Alih Bahasa: Udaya Yusuf. Kepemimpinan Dalam Organisasi. Jakarta: Prenhallindo.

HR. Bukhari : 4801, 5649

HR. Muslim : 3408, 4723

HR. Tirmidzi : 1627, Abu Dawud : 2539, dan Ahmad : 4266, 4920, 5603, 5635,5753 